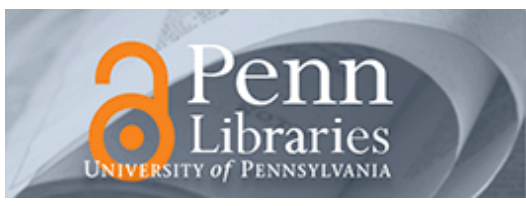

University of Pennsylvania
ScholarlyCommons

Departmental Papers (Classical Studies)

Classical Studies at Penn

1992

\title{
Maternity and Mortality in Homeric Poetry
}

Sheila Murnaghan

University of Pennsylvania, smurnagh@sas.upenn.edu

Follow this and additional works at: http://repository.upenn.edu/classics_papers

Part of the Classics Commons

\section{Recommended Citation}

Murnaghan, S. (1992). Maternity and Mortality in Homeric Poetry. Classical Antiquity, 11 (2), 242-264. http://dx.doi.org/10.2307/ 25010975

This paper is posted at ScholarlyCommons. http://repository.upenn.edu/classics_papers/60

For more information, please contact repository@pobox.upenn.edu. 


\title{
Maternity and Mortality in Homeric Poetry
}

\begin{abstract}
The mythological tradition expressed in early Greek hexameter poetry offers an ancient and influential witness to one of the most pervasive assumptions shaping Western cultural constructions of gender, the assumption that there is a link between two inescapable aspects of the human condition: the fact of being born from a woman and the fact of having to die. That body of poetry, which includes not only the Homeric epics, the Iliad and the Odyssey, but also a number of roughly contemporary texts, such as Hesiod's Theogony and Works and Days and the narratives concerning the Olympian gods that form the Homeric Hymns, is preoccupied with defining human life by exploring the line that separates men and gods. As they carry out this project, these poems follow a widespread tendency to identify mortality, the necessity of dying, with women. Those who bring people into the world by giving them birth are especially linked to their passing out of it as well, an association often expressed in the special place of women in funerary ritual and lamentation.
\end{abstract}

\section{Disciplines}

Arts and Humanities | Classics 


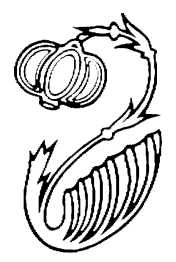

\section{Maternity and Mortality in Homeric Poetry}

Man that is born of a woman hath but a short time to live.

"Burial of the Dead," The Book of Common Prayer

$\mathrm{T}$ HE MYTHOLOGICAL TRADITION expressed in early Greek hexameter poetry offers an ancient and influential witness to one of the most pervasive assumptions shaping Western cultural constructions of gender, the assumption that there is a link between two inescapable aspects of the human condition: the fact of being born from a woman and the fact of having to die. That body of poetry, which includes not only the Homeric epics, the Iliad and the Odyssey, but also a number of roughly contemporary texts, such as Hesiod's Theogony and Works and Days and the narratives concerning the Olympian gods that form the Homeric Hymns, is preoccupied with defining human life by exploring the line that separates men and gods. As they carry out this project, these poems follow a widespread tendency to identify mortality, the necessity of dying, with women. Those who bring people into the world by giving them birth are especially linked to their passing out of it as well, an association often expressed in the special place of women in funerary ritual and lamentation.

This paper has benefited from the questions and responses of those present on the three occasions on which it was delivered in earlier versions: at the NYU conference on "Greek and Greek American Women in Voice and Text," sponsored by the Alexander S. Onassis Center for Hellenic Studies, on April 15, 1989; at Rutgers University on October 4, 1989; and at Bryn Mawr College on November 22, 1991. For specific suggestions, I owe particular thanks to Margaret Bruzelius, Thomas Figueira, and Sarah Winter. 
In a cultural tradition shaped and dominated by the perspective of men, that link frequently takes on a perversely causal character, as if women by giving birth to men were also responsible for their dying. Illogically but all too understandably, women are associated with mortality through the role they play in repairing it, through the capacity to nurture new life within their bodies that, by permitting the perpetuation of the species, offers the only possible counter to individual mortality. In effect, women are held responsible for the need they play so much the larger part in meeting. One prominent way in which this association expresses itself is through depictions of mothers announcing to their children, and in particular to their sons, that they are mortal: mothers transmit the knowledge of mortality to their children in a recapitulation of their original transmission of the mortal condition itself.

This phenomenon-and its widespread quality-can be illustrated from a text belonging to a very different cultural context from that of the early Greek poems with which this discussion will be primarily concerned, Freud's The Interpretation of Dreams. There Freud reports having had a dream in which he went into a kitchen and saw three women, one of whom was twisting something in her hands as though she were making dumplings. His first act of interpretation is to identify the women as the three Fates, but it still remains necessary to make sense of the dumplings: ${ }^{1}$

One of the Fates, then, was rubbing the palms of her hands together as though she was making dumplings: a queer occupation for a Fate, and one that cried out for an explanation. This was provided by another and earlier memory of my childhood. When I was six years old and was given my first lessons by my mother, I was expected to believe that we were all made of earth and must therefore return to earth. This did not suit me and I expressed doubts of the doctrine. My mother thereupon rubbed the palms of her hands together-just as she did in making dumplings, except that there was no dough between them-and showed me the blackish scales of epidermis produced by the friction as a proof that we were made of earth. My astonishment at this ocular demonstration knew no bounds and I acquiesced in the belief which I was later to hear expressed in the words: "Du bist der Natur einen Tod schuldig" ["You owe nature a death."].

In this passage, not only is the mother the one who tells her skeptical son that he is mortal (an isolated action that becomes her exclusive and perpetual function as she is transformed in his dream into one of the Fates), but the proof she employs testifies to her presumed responsibility for the condition she enunciates. Her revelation of herself as earth gives eloquent expression to two common

1. The Interpretation of Dreams, vols. 4 and 5 in The Standard Edition of the Complete Psychological Works of Sigmund Freud, ed. James Strachey (London, 1953-1974), 205. For a discussion of this passage in the overall context of Freud's ideas, see Sarah Kofman, The Enigma of Woman: Woman in Freud's Writings, tr. Catherine Porter (Ithaca, 1985) 71-81. 
identifications: the identification of the mother's body from which the child originates with the place of death to which he must return; and the identification of both those places with the earth. ${ }^{2}$ Like the earth, the mother's body is seen not only as a place of concealment, where the child has been kept in the past and will be kept again, but also as a site of production, where both the child itself and the food through which it is nourished are made. ${ }^{3}$ Here the productivity of the mother's body is evoked through the comparison of her sloughing-off of epidermis, which is the "ocular demonstration" of the child's mortality, to the making of dumplings, clearly a key image for Freud as it provides the link between his childhood memory and his dream. Through that image, this passage offers a distinctively Viennese version of a more general tendency to identify the mother's capacity to provide nourishment as itself an expression of her child's mortality. ${ }^{4}$ It has recently been suggested that we might turn to ancient Greece for liberating alternatives to Freudian models of the female body. ${ }^{5}$ But this echo of associations embedded in the earliest texts of the Western tradition both in Freud's imagination and, if his memory is to be trusted, in the self-presentation of his mother, testifies on the contrary to a powerful continuity between ancient and modern conceptions, at least where this particular set of ideas is concerned.

Turning now to Homer and to the way this set of associations is expressed within the particular values and conventions of Homeric poetry, the notion that mortality is transmitted through the mother and signaled by her provision of nourishment is neatly expressed in a line from the Iliad that comes near the beginning of Book 24. The Greek hero Achilles has met and killed his greatest enemy, the Trojan hero Hector, in battle. But Achilles' desire for revenge against Hector for killing his friend Patroclus has still not been satisfied, and so Achilles holds on to Hector's body, refusing to return it to the Trojans for burial and repeatedly dragging it through the dust suspended from his chariot. This

2. For ancient Greek versions of the equation of women's bodies with the earth, see Page duBois, Sowing the Body: Psychoanalysis and Ancient Representations of Women (Chicago, 1988) $39-89$.

3. This conception is reinforced in the section immediately preceding this passage, where the first stage of interpreting the dream leads to an evocation of the nourishing female breast: "Love and hunger, I reflected, meet at the woman's breast" (204). This is followed by an anecdote about a wetnurse.

4. The equation of women's reproductive functions with cooking is common; as well as being a predominantly female activity in many cultures, cooking is easily analogized to the biological functions of pregnancy and lactation. For ancient Greek notions of the female body as an oven, see duBois (above, n. 2) 110-29. A contemporary example of this equation is furnished by the shout directed at Natalie Tennant, the first woman to try out for mascot at West Virginia University: "Go back to the kitchen and make babies" (New York Times, March 9, 1990, 36-37). Freud's association of one of the Fates with the (as he himself notes) unconventional activity of making dumplings illuminates the significance of their more traditional activity, spinning wool. That attribute also associates their productivity, in a form that is also traditionally associated with women although less readily identified with women's biological functions, with their dual roles of causing and announcing death.

5. See duBois (above, n. 2). 
situation is discussed on Olympus, and Apollo, in particular, criticizes Achilles and says he should give the body back. Hera, on the other hand, strongly objects:

What you have said would be true, lord of the silver bow, if you gave equal honor to Achilles and to Hector.

But Hector is a mortal and he suckled at a woman's breast, while Achilles is the child of a goddess, whom I myself raised and cared for and gave as a wife to a man,

Peleus, who was especially dear to the heart of the immortals, and all you gods went to the wedding.

(Il. 24.56-62)

The definitive difference between these heroes derives from the difference between their mothers: Hector's mother is a mortal woman, Hecuba, while Achilles' mother is a goddess, Thetis. And Hector's mortal heritage is identified specifically with his nursing at his mother's breast, as if he had taken in mortality itself along with his mother's milk. ${ }^{6}$

This association of a mother's care with a son's inescapable death is brought out even more clearly in another Homeric myth, the story told in the Homeric Hymn to Demeter. There Zeus arranges for his daughter Persephone to be carried off by Hades, the god of the underworld, without the knowledge of her mother, the goddess Demeter. In response, Demeter leaves the divine sphere of Olympus, disguises herself as an old woman, and hires herself out to a mortal family as the nurse for their baby boy, Demophoön. In that capacity, she sets out to make him immortal: the baby no longer eats food or sucks in mother's milk (assuming that Hermann's gala métros is a correct reconstruction of line 236), but rather is anointed with ambrosia and flourishes like a god. ${ }^{7}$ And every night Demeter secretly hides the baby in the fire, like a dalos, a brand of wood. This special treatment would lead to Demophoön's immortalization if it were not for the interference of his mother, Metaneira, who one night gets up, sees what is happening, slaps her thighs, and cries out in terror: "My child Demophoön, the strange woman is hiding you deep in the fire and brings me lamentation and

6. While Hera does not explicitly say here that Achilles did not drink mother's milk, there was a tradition to that effect. That tradition is attested in attempts to etymologize Achilles' name as a combination of the negative prefix $a$ - and the word cheile, meaning lips, on the grounds that he did not put his lips to his mother's breast. See Apollodorus, Library 3.13.6, and the other references cited by N. J. Richardson, The Homeric Hymn to Demeter (Oxford, 1974) 237. In the Homeric Hymn to Apollo, which tells the story of the god's birth, it is explicitly noted that Apollo's mother did not nurse him and he was fed nectar and ambrosia instead (H. Apollo 123-25).

7. The Hymn to Demeter further elaborates the connection between eating and mortality when Persephone condemns herself to spending part of her time in the underworld, and thus becomes unable to escape the realm of death altogether, by eating something, specifically a pomegranate seed, while she is there (371-74). On this as one of many parallels between the stories of Persephone and Demophoön, see Nancy Felson Rubin and Harriet M. Deal, "Some Functions of the Demophon Episode in the Homeric Hymn to Demeter," QUCC 5 (1980) 13 n.18. 
bitter suffering [goon kai kédea lugra]" (H. Dem. 248-49). At this point Demeter becomes enraged, puts the baby on the ground, reveals her true identity, and swears that she would have made Demophoön a god if it were not for Metaneira's fatal stupidity - although she also adds that Demophoön will have timè aphthitos, "immortal glory," because she took care of him.

This story is constructed in such a way as to reiterate the connection between mothers and death. The basic assumption that Demophoön's mortality is due to his mother is reinforced by a story in which he theoretically has a chance at immortality but that chance is ruined by his mother, who, with her limited mortal vision, is unable to see that the supposed nurse is a goddess, and whose instinctive concern for her child not only responds to but also causes his inevitable tie to the earth and ultimately to death-that tie being effectively reinstated when Demeter places Demophoön on the ground. Furthermore, Metaneira not only causes her son's death, but she also announces it: her gesture of slapping her thighs signifies impending death, ${ }^{8}$ and the terms in which she alludes to her present anxiety, goon kai kédea lugra, "lamentation and bitter suffering," as well as the terms that are applied to it by the poet (kökusen, "she wailed," 245; olophoromenē, "mourning," 247; oduromene, "grieving," 250) are also proleptic of the mournful lamentation and painful sorrow with which a mother confronts the death of her child. ${ }^{9}$

The possible role of a divine nurse in making a mortal immortal is reflected in a tradition about Heracles, which is known only from relatively late sources. According to this tradition, Heracles-who is often presented as the only mortal to succeed in becoming a god, transcending the heritage of his mortal mother. Alcmena, to take on the immortality of his father, Zeus-was suckled by Hera. This occurred either (in the version of the story depicted in Etruscan art) at the point of his entry into Olympus as an adult in a gesture of adoption, or (in the version told in literary sources) ${ }^{10}$ when he was a baby, at which point Hera, who had bitterly opposed his birth, was tricked by Zeus or otherwise unaware of what she was doing. While this myth might seem to reverse the outcome of the story told in the Hymn to Demeter, our fullest version of it, the version told by the first-century-B.c. historian Diodorus Siculus, is in fact remarkably similar. In that version, Hera nurses the baby Heracles at Athena's suggestion when the two goddesses find him after he has been exposed by Alcmena out of fear of Hera's jealous anger. Heracles tugs on Hera's breast so forcefully that she cannot stand the pain and casts him away, at which point Athena takes him back to Alcmena to raise. While Hera's brief suckling may presage Heracles' ultimate immortalization, the immediate effect of the episode is to reinstate the mortal existence he has to live through first. Hera rejects the mother's role of nursing and the pain

8. Steven Lowenstam, The Death of Patroklos: A Study in Typology (Königstein, 1981) 56-60).

9. On Metaneira as a mourner, see Rubin and Deal (above, n. 7) 12-13.

10. See Lycophron, Alexandra 39, 1326; Diodorus Siculus 4.9.7; Pausanias 9.25.2; Hyginus, Poetica Astronomica 2.49. 
that goes with it, returning him to his mortal mother, who has already tried to kill him once by leaving him exposed on the earth and whose future care will assure his consignment to a life of mortal hardship before his exceptional apotheosis. ${ }^{11}$

The comparison in the Hymn to Demeter of Demophoön in the fire to a dalos, a firebrand, suggestively links this myth to another in which a mother is also responsible for her son's death, the myth of the Aetolian hero Meleager. ${ }^{12}$ This story is best known from Iliad 9, where it is told by Phoenix as a cautionary exemplum for Achilles (Il. 9.529-605); in that version, the role of Meleager's mother, Althaea, in bringing about his death takes the form simply of an angry curse that causes him to die in battle. But it appears that this curse is a rationalization of more magical elements found in another version of the story, which is available to us only in later sources but which probably lay behind the version told in the Iliad. ${ }^{13}$ According to that version, told by Aeschylus, Phrynicus, Bacchylides, Ovid, Apollodorus, and Hyginus, ${ }^{14}$ Althaea learns from one of the Fates at the time of Meleager's birth that he will die when a certain brand of wood lying in the fire is burned up. ${ }^{15}$ She immediately snatches the brand out of the fire and hides it away in a chest. But when Meleager kills one or more of her brothers in a dispute arising out of the Calydonian boar hunt, she takes the brand out of the chest and throws it back on the fire, with the consequence that Meleager dies.

In this myth, the image of the firebrand, which is Meleager's double, or as Aeschylus puts it, "his contemporary from the time he came forth from his mother's womb and cried" (Ch. 608-9), links the mother's act of actually killing the son to her earlier act in giving him birth. The gesture of taking the brand out of the fire is a metaphor for giving birth, as is suggested in the Ovidian version of the story, in which Althaea demands Meleager's death by calling on him to

11. For discussion of this legend and further references, see W. Deonna, "La légende de Pero et Micon et l'allaitement symbolique," Latomus 13 (1954) 140-66, 356-75; Nicole Loraux, Les expériences de Tirésias: Le feminin et l'homme grec (Paris, 1989) 162-68.

12. Jean-Pierre Vernant points out that the motif of the firebrand also connects these stories to a type of myth that expresses hostility to the mother in a different way, making her unnecessary rather than making her a murderer. In myths of that type, which form part of the "dream of a purely paternal heritage [that] never ceased to haunt the Greek imagination," a king's son is born from a brand or spark that leaps from the fire into the lap of a virgin who tends the paternal hearth: Myth and Thought among the Greeks (Boston, 1983) 134.

13. For a survey of the other versions of the Meleager story and an account of their relationship to the one told in the Iliad, see Johannes T. Kakridis, Homeric Researches (Lund, 1949) 11-42.

14. Pausanias 10.31.4 (for Phrynicus) ; Aeschylus, Choephoroi 602-11; Bacchylides 5.94-154: Ovid, Metamorphoses 8.268-546; Apollodorus, Library 1.8.2-3; Hyginus, Fabulae 171-74.

15. The juxtaposition here of the mother with one of the Fates is reminiscent of the connection made by Freud in interpreting his dream. Kakridis (above, n. 13: 14) suggests that in the Meleager story the Fate foretells evil because she is for some reason angry at the mother, which would provide a further parallel with the Demophoön myth, where Demeter both resembles Metaneira as a substitute mother and is angry at her, and where she foretells Demophoön's death as if she were one of the Fates. On the close connection between the motif of divine anger toward a mortal and the motif of identification between the god and the mortal, see Gregory Nagy, The Best of the Achaeans (Baltimore, 1979) 289-97. 
"Give back the life that was given twice, first through birth, then through the snatching away of the brand," ("Bisque datam, primum partu, mox stipite rapto / redde animam," Met. 8.504-5). (Here one might note the resemblance of Althaea's formulation to the proverb to which Freud is led by his mother's lesson: You owe nature a death.) For a mother to impart to her son a life that, like a brand of wood, will inevitably be snuffed out, is already to make him mortal-as is clear from the way, in the Hymn to Demeter, Demophoön's consignment to mortality is accompanied by his removal from the fire. Already implicit in the gesture that in the Meleager story expresses a mother's care is the inevitable sequel of the child's death, a consequence that in the same story occurs in the intensified form of early death brought about by the mother's anger. ${ }^{16}$

The Meleager myth heightens the link between the mother's act of giving birth and the child's death both by constructing a narrative in which she actively causes his death and by representing those acts through the seemingly opposed but fundamentally similar gestures of taking the brand out of the fire and putting it in. The similarity of these gestures emerges when, in the course of reversing her earlier action of removing the brand from the fire, she also repeats it, removing the brand from the chest in which it has been hidden (so that, in effect, she gives birth to him a third time, now at the same time that she kills him). ${ }^{17}$ This similarity is also revealed by the fact that in another version of the story of Demophoön, a version attested in Apollodorus and in an Orphic fragment, the consequence of the mother's crying out is not that the baby is taken out of the fire, but that he is burned up by it: ${ }^{18}$ in this alternative version, leaving the baby in the fire has the same significance as taking him out does in the Hymn to Demeter. The way in which these myths equate motifs associated with birth and death again implies an equation between the place from which the child emerges at birth and the place to which he returns at death, here figured as a fire (which, like the more obvious metaphor of the chest, is conceived of as a place of concealment, so that Metaneira in the Hymn to Demeter cries that Demeter is hiding [kruptei] Demophoön in the fire [249; cf. 239]). The interchangeability of

16. In a forthcoming essay, "Meleager and the Femmes Fatales of Greek Mythology," Charles Chiasson makes a similar point about Althaea's placement of the brand in a chest: he notes that the chest, or larnax, represents not only a safe hiding place but also the kind of vessel in which, in a widely familiar type of myth, a child abandoned by its parents would be exposed and thus consigned to death.

17. Compare also the way in which Metaneira's gesture of slapping her thighs, which leads to Demophoön's removal from the fire, is matched in the Iliad version of the Meleager story by Althaea's gesture of slapping the earth, which accompanies the curse that, in that version, substitutes for placing the brand in the fire (Il. 9.568).

18. Apollodorus, Library 1.5.1; Orphic fragment 49.100ff. The seeming contrast between these two outcomes has led to the theory that the version in which the baby dies was the original one, but that it was replaced by the version in which he lives, an expurgated version that was preferred as being more "soft-hearted and civilized." See Gilbert Murray, The Rise of the Greek Epic, 4th ed. (Oxford, 1934), 337-39. If so, I would argue, the effect of the expurgation is only superficial. 
taking the brand out of the fire and putting it back in again further suggests that a mother's care is so inevitably expressive of death that it might as well lead directly to death instead of to a brief, doomed life, as in the alternative version of the Demophoön story, or that it might as well turn into murderous hatred, as in the Meleager story. ${ }^{19}$

Thus even the most magnificent heroes, figures like Hector, Meleager, and the less widely famous but also distinguished Demophoön, are bound to mortality by the very fact of having mothers. Yet, even if their stories show that this fate is inescapable, these heroes are themselves dedicated to ignoring it. As they struggle to endow their brief lives with significance by doing something memorable and courageous, they are obliged to defy death, to pretend it doesn't exist, and so to disregard what is understood to be their maternal heritage. This denial is dramatized in Iliad 22, at the point when Hector bravely encounters Achilles outside the protective walls of Troy and refuses to be dissuaded by precisely the sign of his own mortality that Hera invokes as definitive in the passage quoted above, his mother Hecuba's breast. As Hector waits to confront Achilles in the decisive encounter that will surely be fatal for him, his parents beg him to return to the city and fight defensively. His father, Priam, first appeals to him only with words, but Hecuba follows Priam's plea by baring her breasts and begging Hector to stay back out of reverence for them.

Hector, my child, honor these and take pity on me, if ever I gave you a breast that causes release from care. Be mindful of them, dear child, and ward off this dreadful man from within the wall.

$$
\text { (Il. 22.82-85) }
$$

Hecuba's gesture is a claim to authority, a reminder of what Hector owes to her that she hopes will make him willing to listen. It is also the most graphic possible

19. The association of women with concealing objects that stand for their own bodies obviously suggests Pandora, with her famous jar, reinvented in later tradition as a box, which she both carries and herself resembles. Pandora, whose origin is told by Hesiod in both the Theogony (535-612) and the Works and Days (42-105), is not the mother of any individual, but, as the first and prototypical woman, the source of the genos gunaikon, "race of women" (Theogony 590), she inevitably has maternal connotations, and she brings about the definitive evils of mortal life, including sickness, old age, and death (Works and Days 90-92) through her birthlike gesture of opening the jar. Those evils further include, in the Theogony version, the need to have children, and, in both versions, a pervasive structure of concealment, whereby good lies beneath seeming evil and evil beneath seeming good, that runs through all aspects of human life. This concealment is found in Pandora herself, who hides a thievish nature under a lovely exterior (Works and Days 60-68, 78); in the works of Prometheus (bones hidden by fat, edible meat hidden by the ox's stomach, fire hidden in a fennel stalk); in the image of hope left behind in Pandora's jar; in the greedy behavior of women who take what men produce into their bellies (Theogony 599); and in the all-controlling fact that "the gods keep the means of life hidden from men" (Works and Days 42). The attribution of human misery to Pandora points to the unspoken model for all this concealment: the woman's body, which hides the unborn child. On the homology between Pandora herself and her jar, see duBois (above, n. 2) 45-47; Pietro Pucci, Hesiod and the Language of Poetry (Baltimore, 1977) 88. 
assertion of what both she and Priam want Hector to take into account: his mortal vulnerability, which makes his encounter with the semidivine Achilles certain to be fatal and thus certain to leave his parents helpless and bereft. But the heroic code to which Hector is bound requires him to ignore even this most persuasive reminder of his mortality, and he stays where he is to await the confrontation with Achilles that will assure his death but also his glory. ${ }^{20}$

The association of maternal care with inevitable death means that signs of that care, like the removal of the brand from the fire in the stories of Demophoön and Meleager, or like Hecuba's breast in Iliad 22, implicitly signal that death is a foregone conclusion, and thus cannot be acknowledged by a hero like Hector, for whom the only respectable response to death is defiance. For a hero to succumb to a mother's care is to stay out of the arena of heroic life and action and thus to earn an obscurity that might as well be death.

This unheroic obscurity is often expressed in Homeric poetry through the mythological motif of concealment by a goddess. ${ }^{21}$ The concealing goddess may be the mortal hero's lover, as is the case of Calypso in the Odyssey, a figure whose name means "Concealer" and who keeps Odysseus for seven years on a remote island while hoping that he will allow her to make him immortal, with the consequence that he is no longer heard of in the heroic society he has left behind, and is presumed to be dead. ${ }^{22}$ But the concealing goddess may also be the hero's mother, as in the case of Aeneas in the Iliad. In Iliad 5, Aeneas's mother, Aphrodite, removes him from the battlefield by hiding him in the folds of her shining peplos, or robe (Il. 5.314-15); related to this is the fact that, within the Iliad, Aeneas never achieves the heroic stature that he might be expected to have. The description of Aeneas hidden under Aphrodite's peplos reveals that this form of maternal care is also based in the mother's body, for it suggests the unborn child's concealment and nurture inside his mother's body. ${ }^{23}$ In Book 3 of the Iliad, Aphrodite extends the same treatment to Paris, who is not her son but simply her favorite, with similar consequences. Paris experiences an absence

20. This scene is closely echoed in a fragment of the Geryon, a lyric narrative by the 7 th/6thcentury poet Stesichorus, in which Geryon's mother Callirhoë implores him not to fight Heracles by alluding both to her grief and to the breast she has given him in the past (see S 13 in Supplementum Lyricis Graecis, ed. Denys Page [Oxford, 1974]). Her gesture anticipates the outcome of an encounter that Geryon, who descends from a pair of minor divinities, perceives as determining whether he is himself mortal or immortal (S $11 S L G)$.

21. On the figure of the concealing goddess, see Deborah Dickmann Boedeker, Aphrodite's Entry into Greek Epic (Leiden, 1974) 39-42, 64-84; Gregory Nagy, "Phaethon, Sappho's Phaon. and the White Rock of Leukas," HSCPh 77 (1973) 156-72.

22. On the significance of Calypso, see Jean-Pierre Vernant, "Feminine Figures of Death in Greece," Diacritics 16 (1986) 62-64.

23. The connection between the goddess's concealing function and her potential maternity, even when the mortal in question is not her son but her lover, is expressed by the version of the myth of Aphrodite and Adonis in which Aphrodite hides Adonis in a chest while he is still an infant and gives him to Persephone (Apollodorus, Library 3.14.4). Here the conveying of the encased child to Persephone again identifies the state of concealment that precedes life with the eventual death that follows on it. 
from battle, the unheroic character of which is emphasized in Book 6 through a contrast with Hector, who refuses to pause in the city and, in particular, rejects both the refreshment of wine and the invitation to linger away from the battle offered him by his mother (Il. 6.251-85).

Both the unheroic significance of this maternal concealment and its association with pregnancy are underscored in a later anecdote illustrating the role of Spartan women in reinforcing the martial ideals of that society. According to Plutarch, when a certain woman saw her sons retreating, she shamed them by raising her skirts to show them her genitals and proclaiming, "Where have you fled to, you slavish cowards? Do you think you can slink back in here where you came from?"- a confrontation that neatly inverts the transaction between $\mathrm{Hec}$ tor and Hecuba in Iliad 22. ${ }^{24}$

The image of concealment by a goddess resembles the image of the brand in the fire in that both images evoke the child's concealment in his mother's body and both are capable of signifying either immortality or death, two states that are equally opposed to mortal life. ${ }^{25}$ But in this group of poems that center on the experience of mortal life, the possibility of immortality is invoked only to be foreclosed: Metaneira's mortal foolishness ruins Demophoön's hypothetical chances; for Odysseus the possibility of staying with Calypso is never a serious option; and Achilles' mother, Thetis, cannot whisk him off his funeral pyre to the White Island of immortality as she does in the Cyclic epic Aithiopis, where Eos, the dawn goddess who is possibly the prototype of all concealing goddesses, similarly secures immortality for her son, Memnon. ${ }^{26}$

One of the signal features of the Iliad is its insistence that, despite the distinction so carefully drawn by Hera in the passage quoted above, Achilles is no more exempt from mortality than is Hector, even if he does have a divine mother. Indeed, throughout the Iliad, the function of Achilles' mother, Thetis, is

24. Plutarch, Sayings of Spartan Women, 241B; cf. Bravery of Women 246A-B, where Plutarch tells the same story about a group of Persian women.

25. On the variable fate of the concealing goddess's mortal lover, which is sometimes death and sometimes immortality, see Boedeker (above, n. 21) 78-82; Nagy (above, n. 21) 171. Notably, however, even when he does achieve immortality, that immortality is often contradicted by a state of physical weakness, frequently as a consequence of aging, which marks his inescapably mortal nature. The clearest example of this is the figure of Tithonus, whom Eos, the dawn goddess, is able to make immortal but not ageless, and whom she in the end hides away in a room, completely devoid of strength (H. Aphr. 218-38). Cf. Hector's fear at Iliad 6.265 that his mother, by offering him wine, will deprive him of strength (mè m'apoguiōsess meneos). On the two possible outcomes of placement in the fire, see Richardson (above, n. 6) 234.

26. On the ruling-out of immortality as one of the chief features distinguishing the Iliad from the other poems of the Epic Cycle, see Jasper Griffin, "The Epic Cycle and the Uniqueness of Homer," JHS 97 (1977) 42-43. On the consequent stress in these poems on those forms of immortality that are compatible with death, namely immortalization in song and immortalization in cult, and the role played by the hero's mother both as nourisher and as mourner in these processes, see Nagy (above, n. 15) 178ff., esp. 181-84, where parallels between Achilles and Demophoön are noted; Dale Sinos, Achilles, Patroklos and the Meaning of Philos, Innsbrucker Beiträge zur Sprachwissenschaft 29 (Innsbruck, 1980) 21-26. 
to highlight Achilles' mortality. As one critic puts it, "that is Thetis' artistic role in the poem - to bring with her when she comes the thought of Achilles' approaching death." 27 Thetis fulfills this role both by announcing Achilles' death, repeatedly and with a prophetic authority deriving from her divine status, and also by anticipating it in her own experience, giving herself over to painful expressions of grief (cf. Il. 18.54-62).

While Thetis's fulfillment of this artistic role is unmistakeable, it may also seem surprising, because she is after all Achilles' immortal parent. It is Peleus, his father, who represents the mortal component in his mixed parentage. Indeed Peleus's responsibility for Achilles' mortality is represented in a myth attested in Apollonius of Rhodes and Apollodorus that assigns the roles played by Metaneira and Demeter in the Demophoön story to Peleus and Thetis: there Thetis places the baby Achilles in the fire at night and Peleus sees her and cries out, whereupon she throws the baby to the ground and flees. ${ }^{28}$ Yet the Iliad makes no allusion to that myth and not only associates Thetis with Achilles' mortality, but presents her as being, like Metaneira in the Demophoön story, responsible for it. In this respect, Thetis's maternity outweighs even her divinity, and her role in the poem provides a remarkable illustration of the phenomenon with which this discussion began, the disproportionate linking of mortality with the mother.

In the mythology surrounding the figure of Thetis that lies behind the Iliad, the history of Achilles' birth is so conceived that Thetis is portrayed as the cause of his mortality. ${ }^{29}$ In a myth known only from the later source of Pindar's eighth Isthmian Ode, but evidently alluded to in the Iliad, Thetis almost has a divine husband instead of the mortal Peleus; in fact Zeus and Poseidon compete to marry her. The goddess Themis, however, reveals a prophecy according to which Thetis is destined to have a son who will be stronger than his father, and advises that, instead of being married to a god, Thetis should be married to a mortal and should see her son die in war. Zeus then arranges for her marriage to Peleusand, as Hera reminds them in Iliad 24, all the gods go to the wedding.

27. E. T. Owen, The Story of the Iliad (London, 1946) 11.

28. Apollonius of Rhodes, Argonautica 4.866-79; Apollodorus, Library 3.13.6. We also know of versions of the Demophoön story in which the child's father is the one who interrupts the goddess. See Hyginus, Fabulae 147; Servius on Virgil, Georgics 1.19, 163; Lactantius Placidas on Statius, Thebaid 2.382; Scriptores Rerum Mythicarum Latini, ed. G. H. Bede, 1.3,107. For a version of the Achilles story in which Achilles' rescue from the fire is preceded by the death there of several other children, as in the alternative version of the Demophoön story (see n. 18 above), see Richardson (above, n. 6) 242; again, this juxtaposition of motifs can serve as a reminder that the life of the child who is saved is pitifully brief. In another well-known tradition about Thetis, the tradition of her attempt to make Achilles immortal by immersing him in the river Styx (Statius, Achilleid 1.269; Servius on Virgil, Aeneid 6.57), she is herself responsible for the failure of her plan. This myth is closely parallel to Demeter's unsuccessful attempt to immortalize Demophoön, as Nagy points out (above, n. 15: 189).

29. This mythology has been investigated in an important recent study by Laura M. Slatkin, to which this discussion is much indebted throughout: The Power of Thetis: Allusion and Interpretation in the Iliad (Berkeley and Los Angeles, 1991). 
By not marrying Thetis, Zeus assures the permanence of his rule, making certain that he will not be overthrown by his son as he himself overthrew his own father, Cronus, when he came to power, and as Cronus himself did also, overthrowing his father, Uranus. By assuring the permanence of his rule, Zeus secures for himself and for the other gods a freedom from change that is one of the salient characteristics distinguishing gods from mortals. One definitive feature of mortal life is that fathers always have sons who ultimately outstrip them, who eventually become stronger than they are. What the myth highlights by making it a special fate attached to Thetis and revealed by prophecy is, in fact, one of the basic features of human life: the recurrent yielding of one generation to another as the human race endlessly renews itself but no one lives forever. As in the myth of Demeter and Demophoön, the existing order is reaffirmed, and its immutability is emphasized, through a story in which an alteration to that order is raised as a possibility but then does not happen. ${ }^{30}$ When Demophoön's mother obstructs his transformation into a god, the fact that a mortal woman's child must also be mortal is reaffirmed. Similarly, when Zeus transfers Thetis, with her power to bear a usurper to her husband, from himself to Peleus, he reasserts his own divinity and Peleus's mortality.

In both myths a crucial role in perpetuating this order, in which the power of the gods depends on the continued mortality of human beings, is assigned to women in their capacity as mothers, and the story of Thetis further extends the deadly implications of maternity. Not only can the mother be seen as bringing mortality to the son whom she bears and nurtures, but the same kind of logic can also portray her as bringing mortality to her husband as she presents him with the child who will eventually displace him. This role is dramatized, although displaced onto a divine setting, in the accounts of how both Cronus and Zeus overthrow their fathers told in Hesiod's Theogony; each does so at the instigation of his mother and with her help, so that the mother is seen as conspiring with the son to overthrow the father. ${ }^{31}$ In her role as biological link between father and son, a mother brings death to both-binding the father to the son who will overthrow him, and binding the son to a mortal father and thus to a legacy of

30. Another such episode is the passage in the Iliad in which Zeus contemplates rescuing his son Sarpedon from his fated death and then decides not to (Il. 16.431-61). What is important here is not the implication, which has troubled many readers, that Zeus can overrule fate, but the way the suggestion that he might do so serves to emphasize the fact that he does not: even though Sarpedon is the son of Zeus, he is also the mortal son of a mortal mother, Deidameia, and so must die. For the comparable treatment of Anchises' mortality in the Hymn to Aphrodite, and for the way this mythical tradition generally uses speculation about impossible outcomes to explore and reaffirm mortal constraints, see Peter Smith, Nursling of Mortality: A Study of the Homeric Hymn to Aphrodite (Frankfurt, 1981) 88 and nn. 115-17.

31. Another comparable episode occurs in the Homeric Hymn to Apollo, where Hera, angry at Zeus for giving birth to Athena on his own, prays to have a son who will surpass Zeus by as much as Zeus surpasses his father, Cronus (H. Apollo 306-42). At this point, like Althaea when she curses Meleager, she slaps the earth; on the parallel, see Lowenstam (above, n. 8) 71. Because of Zeus's supreme power, however, Hera's wish goes unfulfilled. 
ultimate death. This mythological background shows how Thetis can be seen as responsible for Achilles' mortality even though she is herself a goddess. Her capacity for motherhood has led to her marriage to Peleus, which means humiliation for her and eventually death for Achilles. In effect, she has made Achilles mortal by causing him to have a mortal father.

The conjunction between a father's mortality and the maternity of the female figure who bears his child is dramatized in another myth from the same tradition, the myth told in the Homeric Hymn to Aphrodite. There Zeus takes revenge on Aphrodite for subjecting him and the other gods to unions with mortals by making her fall in love with a mortal man, the Trojan prince Anchises. Like Demeter in the Hymn to Demeter, Aphrodite visits the realm of mortals herself disguised as a mortal, and there she meets and seduces Anchises. After an episode of lovemaking in which she becomes pregnant with the future hero Aeneas, Aphrodite reveals herself to Anchises in a long speech in which she gives voice to her own sense of pain and humiliation at being mated to a mortal. In the course of this speech, she announces Anchises' mortality as if she were disclosing some special oracular knowledge: ${ }^{32}$

If, such as you are now in form and frame, you could live on and be called my husband, then grief would not envelop my careful mind.

But soon common old age will envelop you, pitiless old age, which someday stands beside all human beings, deadly, wearying, hated even by the gods.

$$
\text { (H. Aphr. 241-46) }
$$

Aphrodite's announcement takes on a powerful authority as she combines the roles of goddess asserting herself before a helpless mortal, like Demeter revealing herself to Metaneira, and mother, who bears within her body Anchises' heroic but mortal son, the son whose existence may mitigate Anchises' inevitable old age but is nonetheless implicated in it. In this hymn, as in the Hymn to Demeter and the story of Thetis, it is notably Zeus's role to force upon these female goddesses a connection with death that comes through their capacity for motherhood, whether as the sorrowing mothers of actual mortals, as in the cases of Aphrodite and Thetis, or through the symbolic death of Persephone, as in the case of Demeter.

To return to Thetis, her role in the Iliad is a complicated one, in that she functions simultaneously as Achilles' divine patron, and thus as the source of his hopes for glory, and as his mother, and thus as the source of his ultimate death.

32. The prophetic tone of Aphrodite's words takes on a particular significance if, as has recently been argued, her union with Anchises is to be understood as the last such union, so that she is, in fact, ushering in a new era in which the distinction and isolation of mortals from gods is intensified. See Jenny Strauss Clay, The Politics of Olympus: Form and Meaning in the Major Homeric Hymns (Princeton, 1989) 169, 183. 
She can be said to combine in one figure the contrasting roles played by the two maternal figures of the Hymn to Demeter, the divine Demeter, who brings Demophoön immortal glory, and the mortal Metaneira, who makes him mortal. Thus, unlike Hecuba, she is not shunned by her son, but sought out by him as a source of help and as a comforting interlocutor in many intimate conversations.

The complexity of Thetis's role is reflected in the ambiguous character of the most famous of her announcements to Achilles of his mortality. This is the announcement that he recalls in the speech in Book 9 of the Iliad in which he rejects the overture of Agamemnon's ambassadors, who offer him a series of gifts in exchange for his return to battle. As he moves in that speech from rejecting Agamemnon to rejecting the entire heroic enterprise of fighting for the sake of prizes and the honor they convey, he asserts that such prizes are simply not worth risking one's life for since, once lost, life can never be regained. He then goes on to describe the famous choice with which he is confronted:

For my mother tells me [mētèr gar te me phèsi], the goddess Thetis of the silver feet,

that I carry two possible fates toward the final point of death.

If, staying here, I fight around the city of Troy,

my homecoming is destroyed, but I will have unending fame.

If I go back home to the beloved land of my fathers,

my great fame is destroyed, but a long life

will be mine, and the final point of death will not come quickly.

(Il. 9.410-16)

Thetis's message, as it is reported by Achilles, is a finely balanced statement that combines both elements of her double role. In part, it signifies the distinction from other mortals that comes from having a divine mother: it represents a special access to divine knowledge, which endows Achilles with a privileged perspective from which he can choose his destiny with unique foresight. And Achilles here experiences his mother's message as empowering; it forms the basis of his rejection of Agamemnon's offer, allowing him to assert his independence from other men and to make the choice that no other hero would be capable of.

But Thetis's message to Achilles is a double one. In addition to offering those privileges he finds empowering-closeness to the gods, freedom of choice - it is also, like Aphrodite's words to Anchises, a relentless assertion of mortality. The necessity of death is reiterated throughout his report of it: his capacity to choose is formulated as carrying "two possible fates toward the final point of death." The choice of a long life is expressed as only a postponement of that inevitable moment: "and the final point of death will not come quickly." The account of each choice contains a reminder that something inevitably perishes, whether it is the opportunity to return home, lost through an early death, or unending fame, sacrificed for the sake of a temporary reprieve. 
Achilles' response to this ambiguous message is to embrace that aspect of it that suggests he is different from other men and so to continue his strategy of staying out of battle. That strategy has, in fact, been recommended to him by his mother (Il. 1.421-22), and it is made profitable for Achilles through her influence over Zeus. By exercising that influence, Thetis assures that Achilles' absence causes the war to go badly for the Achaeans and thus that his absence leads not to his dishonor, as it would for ordinary heroes, but to his greater glory. Because Achilles' mother is divine, Achilles can respond to her message differently from the way Hector responds to his mother, not ignoring her to return to battle, but heeding her and staying away; with Thetis's help, he is able-at least for a while - to make the concealment associated with a mother's attention into a source of strength.

But because Achilles' mother is his mother as well as a goddess, he is ultimately not different from Hector, but equally mortal. The plot of the Iliad moves from Achilles' rejection of the embassy in Book 9 toward a gradual clarification, for us and for Achilles himself, of the mortal nature even of the greatest of heroes, even of one who has a divine mother, and thus toward an effacement of the difference between him and other, more ordinary figures such as Hector. As this process of clarification is carried out through the evolving plot, Thetis's message of mortality is repeated, but now in unambiguous terms. In Book 18, Achilles tells Thetis that he is determined to return to battle to kill Hector-a point he introduces by telling her that she will now experience great grief-and she responds by telling him that he will certainly die soon: "I will then lose you soon, my child, given what you are saying / for your death is waiting for you immediately after Hector's" (Il. 18.95-96).

The culmination of this growing stress on Achilles' mortality comes in Book 24, when Achilles finally lets go of Hector's body. Achilles' relinquishing of the body implicitly expresses an acceptance of death for others and finally also for himself. It constitutes an admission that there is nothing more he can do in response to Patroclus's death: Hector is dead and cannot be made to pay any more times for Patroclus's life. It also constitutes Achilles' acceptance of his own death, which, as Thetis has told him, is fated to follow soon after Hector's. At the same time, it involves an expression of fellowship, as Achilles shows compassion to his enemy Priam, offers him hospitality, and willingly enters into an exchange with him, a series of gestures that signal Achilles' new awareness that he is not ultimately different from anyone else. The significance of Achilles action in returning the body is captured well in Hera's protest when Apollo first proposes it, quoted earlier, on the grounds that this gesture of capitulation erases the distinction between Achilles, the son of a goddess, and Hector, who suckled at the breast of a mortal woman.

In a doubling that is characteristic of Homeric poetry, the Iliad offers two accounts of Achilles' crucial change of heart, one motivated at the divine level, one at the human. On the divine plane, the gods decide that Achilles has to give 
up the body, and so Zeus summons Thetis to Olympus and instructs her to tell Achilles to do so. Thetis thus serves as an emissary of Zeus, once again bringing Achilles the message of his own mortality, now in the form of the necessity of submitting to Zeus, whom earlier he had seen as his helper. But, even though Achilles does indicate his acquiescence to Thetis, much less narrative space and emotional weight is given to that exchange than to the parallel human action: Priam's courageous journey to Achilles' camp and his miraculous success in persuading Achilles to give up the body. Priam is able to persuade Achilles by making him remember his own father, Peleus. He evokes an image of Peleus, at home in Greece, old and bereft, and longing to see his son; this image releases in Achilles a sense of grief and compassion that allows him finally to take pity on Priam and honor his request. At this crucial turning point we see Achilles thinking about his father as he has hardly done before, and his father becomes a presence in the poem as he has not been earlier. ${ }^{33}$

Thus Achilles' fullest confrontation of the truth transmitted to him by his mother takes the form of remembering, of acknowledging, his mortal father. Achilles' spiritual journey from a sense of empowering superiority to a deepened consciousness of his own mortal state finally retraces the link between his mother, with her special capacity to communicate mortality, and the identity of his father - a link that is also implied in the juxtaposition of her command and Priam's evocation of Peleus as parallel causes of Achilles' ultimate gesture, and also in the poem's various references to Thetis's past history, in which, as we have seen, she is given a mortal husband so she can bear a mortal son. Among those references is Hera's allusion, in her protest at the beginning of Book 24, to Thetis's wedding to Peleus, which, by evoking Achilles' mortal father, implicitly undermines Hera's contention that he is superior to Hector.

The associations governing the hero's response to his parents that, as this discussion has shown, help to shape the plot of the Iliad also play a role in the other Homeric epic, the Odyssey, even in the least overtly mythological sections of the poem, those having to do with the figure of Telemachus. While the Odyssey's central hero, Odysseus, with his adventures in unearthly realms and his glorious record as the conqueror of Troy, brings to the poem all the intensity and mythological grandeur of the Iliad, his son, Telemachus, acts out a more commonplace story, and the attention given to him signals the Odyssey's shift of focus not only to a peacetime setting but also to what would have been for its original listeners a more familiar social world: Odysseus's extended household on the somewhat provincial island of Ithaca. Nonetheless, Telemachus shares with the more imposing Achilles a story of growing awareness that follows a

33. The most significant earlier reference to Peleus comes in Book 9 , where he is similarly invoked as part of an attempt to persuade Achilles to act out of pity toward other men: in the hopes of inducing Achilles to return to battle, Odysseus quotes Peleus's parting words to his son, in which he urges him to act out of philophrosune, fellow feeling (Il. 9.252-60). At that point, of course. Achilles is deaf to the meassage that comes from his father. 
similar path from a message of mortality conveyed to him by his mother, but rejected by him, to the recognition of his mortal father.

When we first encounter Telemachus at the opening of the poem, he characterizes his situation with a formulation that strikingly recalls Achilles' words in Iliad 9. We see Telemachus through the eyes of Athena, who has arrived disguised as an old family friend for the purpose of stirring him to action. He is sitting in the hall of his father's house, now thrown into disarray by his mother's suitors, and fantasizing about his father's return. Athena announces that she can see in him a resemblance to Odysseus and asks if he is Odysseus's son. Telemachus replies:

My mother tells me [mètēr men t' eme phèsi] that I am his son, but I don't know. No one knows his own parentage.

If only I could have been the son of some very fortunate man, who reached old age in the midst of his possessions. But now this one has become the most ill-fated of mortal men, the one whose son they say I am, since you ask me.

(Od. 1.215-20)

Here Telemachus's mother, Penelope, plays out explicitly her role as link between mortal son and mortal father by being the one who tells her son who his father is. The similarity here of Telemachus's words, mètèr men t' eme phèsi, to Achilles', mètér gar te me phèsi, at Iliad 9.410, although not, because of the formulaic nature of Homeric language, to be interpreted as a deliberate echo, points to an underlying similarity to conception. What the story of Thetis reveals about the implications of motherhood, that mothers make their sons mortal by making them the sons of mortal fathers, clarifies the significance of Penelope's message to Telemachus. By telling him who his father is, she is conveying the same message as Thetis does in the speech reported by Achilles: that sooner or later he has to die.

A particularly interesting feature of the Odyssey passage is the skepticism with which Telemachus responds to what Penelope tells him. He tries to ward off his mother's message, casting doubt on its authority and wishing that his father could be someone other than Odysseus, who, as far as he knows, has had the supreme misfortune of dying far from home where his death cannot be honored and memorialized and where he can be of no use to his son. By investing the question of his paternity with doubt, he lends his mother's straightforward message the riddling, ambiguous quality that is inherently present in Thetis's announcement of Achilles' choice. Thus Telemachus obscures his mother's message, ignoring it much as Hector ignores Hecuba's breast, and allowing himself to enjoy the fantasy of a superior heritage much as Achilles for a time revels in the actual superiority of his own semidivine heritage. By refusing to assimilate his mother's message, Telemachus is able to keep open a sense of possibility and hope. His doubt creates a mystery for him to solve that drives the plot of the 
early part of the poem, which deals with his journey away from home in search of news of his father. This journey is Telemachus's somewhat mundane, but nonetheless consequential, version of the heroic quest, and he carefully avoids letting his mother know about it, escaping the expressions of concern with which she might try to hold him back (Od. 2.372-76).

In the course of his journey Telemachus learns by consulting other warriors who have returned from Troy that he indeed does bear the marks of Odysseus's paternity and that Odysseus is someone whose son he should want to be. The culmination of this quest comes about two-thirds of the way through the poem, in Book 16, when the two parts of the plot dovetail so that Telemachus returns home just as Odysseus too succeeds in returning, and the son encounters his father for the first time in his adult life. The father he encounters is a hero who fully equals or even surpasses Achilles in stature, but he is also, as is Achilles, a figure whose development through the poem devoted to him represents the growing realization of a fully mortal condition. Odysseus's story opens with his rejection of Calypso's offer to make him a god if only he will stay with her; thus the desire to return home that motivates his departure from her and all his subsequent struggles represents the explicit choice of a mortal over an immortal life. The rewards he chooses to return to, his home and his family, are the compensations specifically of mortal existence; prominent among these is his son, who will carry on his line, and who is precious to him precisely because he himself cannot live forever-and disturbing as well for the same reason. The son plays an ambiguous role in his father's life, as both a second self who preserves him from annihilation and a usurper who reminds him of his own mortal limits. This ambiguity is reflected in the way a certain measure of friction is mingled with their rejoicing when Odysseus and Telemachus are reunited.

One aspect of their reunion that this friction illuminates is the way Telemachus's introduction to his father is also an affirmation of his father's identity as a mortal. At first, Odysseus is wearing the protective disguise of an old beggar, and when, with Athena's help, he returns to his true form as a radiant hero, Telemachus is dazzled and thinks he must surely be a god. Odysseus is then obliged to set him straight: "I am not a god. Why are you comparing me to the immortals? $?^{34}$ / I am your father, the one for whom you're groaning / as you endure many sorrows and put up with the outrages of men" (Od. 16.187-89). Odysseus's somewhat testy insistence on this point serves not only to portray an inevitable tension between father and son, but also to emphasize that what Telemachus has already been told by his mother but only now really recognizes-the identity of his father-means that he must also recognize that he, like Achilles, is the son of a mortal. That connection is here highlighted by the way Odysseus's words conjure

34. The same formula is employed by Aphrodite in the Hymn to Aphrodite when she falsely insists to Anchises that she is a mortal. In the next line she reiterates her supposed mortality by claiming that gunè de me geinato mètēr, "a woman was the mother who bore me" (H. Aphr. 109-10). 
up the earlier scene in Book 1 in which Telemachus both reports and rejects his mother's message.

For Achilles, the recognition of his father involves a loss, a new acceptance of impermanence that accompanies the shift of his focus away from a divine to a mortal heritage. The cost to him of this shift can be measured in his reluctance to acknowledge it, as he tells Priam that he is giving Hector's body back only because his mother told him to and not because of anything Priam himself has done (Il. 24.560-62). In the context of the Odyssey, with its untragic plot, its celebration of ordinary mortal pleasures, and its representation of motherhood primarily through the mortal Penelope, Telemachus only stands to gain by following the heroic pattern of ignoring the message of mortality as told by his mother and confronting it instead in the figure of his father. Not only does that ignorance inspire the efforts that give his life meaning and bring him glory, but the message of mortality is mitigated as well as affirmed in the meeting of father and son. In the patriarchal values of the Homeric world, the counter to mortality embodied in the production of children is centered in the paternal line, in the transmission of an undying heritage from father to son. As father and son actually meet in the Odyssey — as they do only in Achilles' mind in the Iliad - the continuity of that transmission is joyfully assured, even as the sad need for it is implicitly reaffirmed.

The importance of the progression traced by Telemachus for the central values of the Odyssey can be seen in the way that same progression also occurs in the experience of Odysseus. Odysseus departs from a meeting with his mother in the underworld, the realm of death, to reclaim his home in a series of encounters with all the other members of his family, a series in which she evidently need not figure and that culminates in Book 24 in an encounter with his father. There Odysseus effectively rejuvenates his father and draws him into a celebration of the paternal line, in which three generations of male family members are united as Telemachus, Odysseus, and Laërtes join forces in the battle against the suitors' relatives.

This, then, is the role mothers play in the lives of their sons in these heroic narratives, their position in the hero's trajectory of flight from and ultimate reconciliation with his mortal nature. ${ }^{35}$ But while these poems may be primarily focused on the experiences and consciousnesses of male heroes, those maternal figures do also have their own stories, and they speak not only with their bodies or through the quotations of their sons, but with their own voices as well. What is striking is the extent to which those voices are given over to grief and lamentation. In the Iliad, as has already been mentioned, Thetis is several times seen grieving in advance over the inevitable death of Achilles, through her shameful

35. For Freud's comparable trajectory, which involved relearning what he had been told by his mother from a university professor and reformulating the insights of maternal mythology through the masculine science of psychoanalysis, see Kofman (above, n. 1) 76-79. As Freud himself noted, a crucial stimulus to the development of that science was provided by the death of his father (above, $n$. 1: 4 .xxvi). 
and wrenching situation as the mother of a mortal coming as close as any god can to a direct awareness of what it is like to be human. Similarly Hecuba figures prominently as one of the mourners around Hector's body, and hers is one of the lamenting women's voices that bring the poem to a close. The notion that women are the prime carriers of mortality, the ones who communicate it to their children, leads to the representation of their subjective experience as an overwhelming consciousness of mortal loss. These depictions of mourning mothers express a sense running through the mythological tradition on which the Homeric epics draw that mourning is essentially continuous with motherhood, an experience that begins with the pain of childbirth. ${ }^{36}$ That pain extends itself in the mother's anxious care for the child, a form of care that already has the character of mourning, as is clear from the diction through which Demeter's concern for Demophoön is equated with lamentation, or from the scene in which Hecuba reminds Hector of her breast while also anticipating the grief she will feel on his death (Il. 22.82-89). Not only are mothers blamed for mortality through being held responsible for it, but they are effectively punished for it as well through being made to feel its painful consequences most keenly. ${ }^{37}$

The Odyssey, with its wider perspective and its largely domestic setting, offers a much fuller exploration of female experience than does the Iliad, largely through its central female figure, Penelope. ${ }^{38}$ And yet Penelope's role in the poem is notably also dominated by weeping, lamentation, and grief. Penelope's grief is brought about both by the absence of her husband and by her concern for her son, and it is prolonged unnecessarily until a very late point in the plot of the poem. Penelope is strikingly absent from the joyous reunion of Odysseus and Telemachus that occurs in Book 16, even though it is she who has created the link between father and son that is there being celebrated. Not only is she left out of that first meeting, but her exclusion is continued for a long stretch of the narrative as Odysseus and Telemachus keep her from finding out that Odysseus has returned. While Odysseus and Telemachus encounter one another at the edge of the estate and together plot Odysseus's recovery of his former position, Penelope is alone in the house struggling with the dilemma that has oppressed her throughout the poem.

36. On childbirth as the prototype of human pain and suffering in Greek thought, see Nicole Loraux, "Le lit, la guerre," L'Homme 21 (1981) 37-67, reprinted in Les expériences de Tirésias (above, n. 11) 29-53.

37. On mothers as the definitive representatives of mourning in ancient Greek culture, see Nicole Loraux, Les Mères en deuil (Paris, 1990), esp. 77-85, for the way the frequent portrayal of mothers as the murderers of their sons makes maternal mourning an expression of remorse as well as of loss.

38. For a fuller analysis of the role of Penelope in the Odyssey that complements the one offered here, see my "Penelope's Agnoia: Knowledge, Power, and Gender in the Odyssey," Helios 13 (1986) 104-15, and Disguise and Recognition in the Odyssey (Princeton, 1987) chap. 4. For a recent treatment of Penelope that explicitly adopts a different point of view, see John J. Winkler, The Constraints of Desire (New York, 1990) 129-61. 
In Penelope's own experience of it, her simultaneous connection to both her husband and her son does not mean creating a deeply valued link; rather, it means being painfully caught between the two of them. Penelope's loyalty to Odysseus demands that she do nothing, remaining in the house, putting off her suitors, and keeping Odysseus's place open for him. At the same time, her loyalty to her son demands that she step aside and allow him to take over his father's house, and particularly that she resolve the problem of the suitors, who are wasting the resources of the household as they wait for her decision. The dilemma she faces illuminates the difficult role of a wife and mother in the patriarchal Homeric household, effectively translating the vision of motherhood as the means by which women bring sorrow and death to both father and son, expressed mythologically in the figure of Thetis, into a concrete social situation.

As long as Telemachus is still a child, Penelope's strategy of waiting for Odysseus is clearly appropriate, but the poem opens at the point when he is reaching manhood-as the journey he takes demonstrates-and his growth places her in an intolerable position, in which she must betray either her husband or her son. Among the most powerful accounts of the pain this situation costs her is the description she gives to Odysseus when he meets with her in Book 19 in the disguise of a wandering beggar. There Penelope compares herself to the nightingale, a figure from mythology that serves as an archetypal emblem of ceaseless female grief.

As when the daughter of Pandareus, the greenwood nightingale, beautifully sings, at the very beginning of spring, sitting in the thick leaves of the trees, and ever varying her song, she sends forth her resonant voice, mourning her dear child Itylus, whom once, with bronze, she killed in mad blindness, the son of Lord Zethus, so also my own heart, divided, is pulled this way and that waywhether I should stay by my child and keep everything safe, my property, my serving women, and the great, high-roofed house, honoring the bed of my husband and the voice of the people, or should I finally go away with whoever is best of the Achaeans, wooing me in the house and offering endless gifts?

My son, as long as he was still a child and unable to think for himself, kept me from marrying and leaving the house of my husband.

Now that he is big and has arrived at the point of young manhood, even he is praying that I leave the house,

since he worries about the possessions, which the Achaeans are devouring.

(Od. 19.518-34)

The story of the nightingale underscores the relationship between maternal grief and a mother's responsibility for her son's mortality, because she is not only the mother of Itylus, but (like Meleager's mother, Althaea) also his killer. Her 
intense and perpetual grief expresses her dual role as murderer and chief mourner, both the one who has brought about his death and the one who suffers the most because of it. ${ }^{39}$

While the myth of the nightingale suggests that a mother's grief is warranted because she actively brings her son's death upon herself, Penelope's comparable suffering shows how the same grief is imposed upon a mother who is not literally her son's murderer. Simply by virtue of her motherhood, she is regarded with suspicion by both her husband and her son; this is expressed in the way both conceal their plans and purposes from her so that she remains in the dark throughout the concluding section of the poem, which builds toward her decision. As mentioned above, Telemachus keeps his journey a secret from her and only tells her about it afterwards when she insists. Odysseus conceals his presence from her as he does not from Telemachus, with the result that her grief is actively prolonged: she is placed in situations, as when she voices her similarity to the nightingale, in which Odysseus observes her suffering but deliberately refrains from alleviating it, as he could by telling her that he has returned.

As a consequence of this treatment, Penelope is not only made to suffer for her maternity, but she is also deprived of a true understanding of the situation in which she finally has to act, so that she makes her choice in isolation and in ignorance. The decision she makes is the inevitable one, the one that acknowledges the passage of time and the definitively mortal replacement of father by son. She announces a contest among her suitors that involves stringing and then shooting a bow left behind by Odysseus. This contest, she imagines, will bring her a new husband and will allow her to leave the house so that Telemachus can take over his rightful place there. In effect, she chooses for her son and for the ongoing process of succession he represents, against her husband and against her own desires. ${ }^{40}$

39. Different accounts of the nightingale story give different reasons for her murder of her son. In the more familiar version told by Apollodorus (Library 3.14.8) and Ovid (Metamorphoses 6.424$674)$, the woman who becomes the nightingale, Procne, is taking revenge on her husband, Tereus, for raping her sister, Philomela. In Penelope's version, we are told simply that she is motivated by aphradia, "blind folly." Notably, this quintessentially human blindness is also the quality through which, according to Demeter in the Hymn to Demeter, Metaneira brings about Demophoön's consignment to mortality (cf. aphradiesi at H. Dem. 257). Penelope's unspecific evocation of this quality suggests that, whatever particular scenario may lie behind her account (for possibilities, see Joseph Russo's comment on this passage in A Commentary on Homer's Odyssey III [Oxford, 1992] 100), the story she tells shares with that of Demophoön an underlying assumption that for a mother to cause her son's death is automatically inherent in the human condition. On the nightingale, with her combined feelings of loss and remorse, as the paradigm of female mourning, see Loraux (above, $n$. 37) 84-97. In particular, Loraux notes that one of the possible scenarios for Penelope's version of the story associates the nightingale with Niobe, another mother who is both responsible for her children's death and an exemplary mourner (88).

40. Thus it is perhaps significant that the contest of the bow provides the context for the one further instance in the Homeric epics of a son's reference to what his mother tells him that is formulated similarly to $I l .9 .410$ and $O d$. 1.215. As the contest is being set, Telemachus notes that his mother tells him (mètēr men moi phèsi philē) that she will leave the house with a new husband; he then goes on to express embarrassment that his own reaction to this message is to laugh and feel joy. presumably a response to the way her gesture is ultimately to his advantage (Od. 21.103-6). 
As it turns out, Penelope's action has the opposite result from what she intends. What she experiences as a sad surrender to the pressure of time and a regretful activation of the relentless process by which mortal father is replaced by mortal son actually reinstates the long-absent Odysseus and suspends the passage of time. Because he is secretly present, the contest makes possible Odysseus's successful return, placing in his hands the weapon with which he can defeat the suitors and a token by which he can prove his identity and reclaim Penelope as his wife.

Odysseus and Telemachus, by excluding Penelope from the knowledge they both enjoy of the happy consequences toward which her action leads, force her to act out an association with the ceaseless process of change that is a hallmark of mortal life. The male characters of the poem thus bring about a reconfirmation of the assumptions about women that are built into the mythological fabric of both the Iliad and the Odyssey. At the same time, by allowing her to suffer unnecessarily, they perpetuate the process by which women are made to pay with grief for their generative power, a power the poem acknowledges by making Penelope's gesture, however she understands it, the decisive event of the plot.

The importance thereby attributed to Penelope's role does, of course, bring with it a sympathetic focus on her and on her state of mind, a focus through which she comes to occupy the emotional center of the poem and emerges as a courageous and affecting figure. As readers of the Homeric epics we certainly must acknowledge and prize the remarkable sympathy the poems do display for the difficult positions in which their female characters are placed, most extensively through the portrayal of Penelope, but also through many other female figures both mortal and immortal, including Hecuba and Thetis. But we also have to recognize that sympathy and the pain to which it responds as part of the larger pattern sketched here-as part of the unequal and unsought bargain by which women, by virtue of their capacity for motherhood, are assigned a disproportionate share in bearing the burden of mortality. 